\title{
Petrographic and mineral variability of the rocks accompanying selected coal seams of the Poruba beds and their influence of the trace elements content
}

\section{Introduction}

Trace elements in the barren rocks accompanying the coal seams in the Upper Silesia Coal Basin (USCB) have, until now, been the subject of only a few studies dedicated mainly to the rocks from the bands and less frequently from the roofs and floors of coal seams (Adamczyk 1994a, b, 1997, 1998; Chodyniecka 1973; Chodyniecka and Wilk 1979; Chodyniecka et al. 1994; Parzentny 1992, 1999; Hanak and Kokowska 2002; Hanak and Kokowska-Pawłowska 2003).

The authors of these studies were trying to identify the magnitude and character of the differentiation of trace elements present in barren rocks and to determine its reasons.

Certain regularities have been observed in the content of the trace elements in barren rocks, i.e. always high but variable content of $\mathrm{Ba}, \mathrm{V}, \mathrm{Zn}$, and $\mathrm{Mn}$ in all petrographic types represented by these rocks. The lowest content exhibited such trace elements as B, Co, Cd, Ag, Sr, and Li (Adamczyk 1998; Chodyniecka et al. 1994; Hanak and Kokowska 2002; Hanak and Kokowska-Pawłowska 2003). In that way, the differentiated presence of trace elements demonstrates also differentiated presence in petrographic types of rocks dependent

* Ph.D. Eng., Institute of Applied Geology, Silesian Technical University, Gliwice, Poland; e-mail: magdalena.kokowska-pawlowska@polsl.pl 
on many factors, from which different chemical characters of the sedimentation environment of roof rocks, floor rocks, and bands rocks in coal seam should be mentioned. Differentiated lateral variability of element concentrations in petrographic types of barren rocks may also suggests an influence of differentiation of alimental environments, from which the rock material originates (Hanak and Kokowska-Pawłowska 2004, 2006).

An increasing trend of the content of some trace elements, like $\mathrm{Be}, \mathrm{Cr}, \mathrm{Ba}$ and $\mathrm{V}$ in the presence of clayey minerals, $\mathrm{As}, \mathrm{Co}, \mathrm{Cd}, \mathrm{Ni}$, and $\mathrm{Mo}$ in the presence of sulphides, and $\mathrm{Pb}, \mathrm{Zn}, \mathrm{Co}, \mathrm{Mn}$, and $\mathrm{Ga}$ in the presence of carbonates have also been observed.

Until now, no evident results have been found which could allow us to determine the relation between the concentration of these elements and the mineral (or chemical) composition of the barren rocks (Polański 1988; Migaszewski and Gałuszka 2003; Hawa Bibi et al. 2008).

The presented work contains results of petrographic-mineralogical research of rocks which coexist with coal in selected seams from Poruba beds $(610,620$, and 630). The research was conducted on coal samples taken from immediate roofs, floors, and bands of the seams. Rock samples were collected in different areas of USCB, namely from western part of

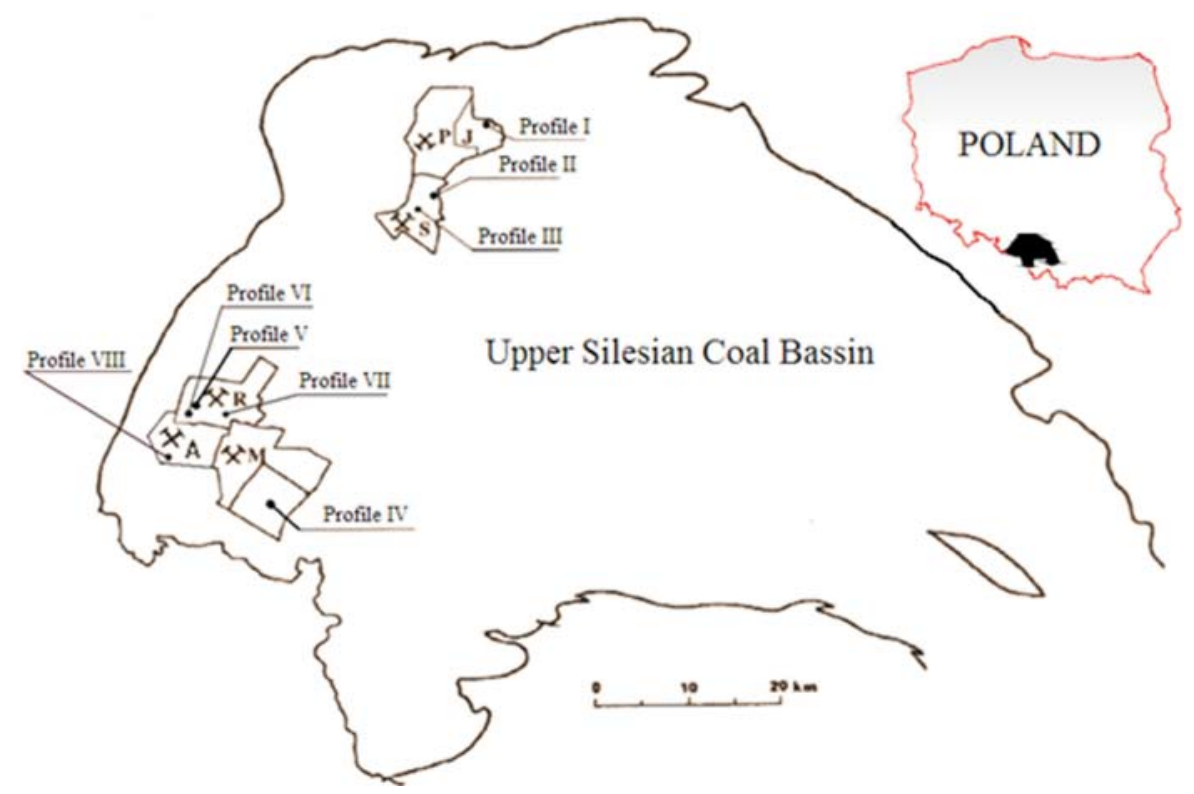

Fig. 1. Localization the coal seams from which the rock samples were taken from

J - ZWSM Jadwiga, P - earlier Pstrowski coal mine, S - Sośnica coal mine,

M - Marcel - field 1 Maj coal mine, R - Rydułtowy coal mine, A - Anna coal mine.

Sample locations: I i II - coal seam 610; III, IV, V, VI - coal seam 620; VII i VIII - coal seam 630

Rys. 1. Lokalizacja pokładów, z których pobrano próbki skał

J - ZWSM Jadwiga, P - dawna KWK Pstrowski, S - KWK Sośnica,

M - KWK Marcel - Ruch 1 Maja, R - KWK Rydułtowy, A - KWK Anna.

Miejsca pobrania próbek: I i II - pokład 610; III, IV, V, VI - pokład 620; VII i VIII - pokład 630 
Bytom syncline (ZWSM Jadwiga), north-western edge of the main syncline (Sośnica coal mine), western part of Jejkowice syncline (Rydułtowy and Anna coal mines), and southern flank of Chwałowice syncline (Marcel, field 1 Maja coal mine).

The method of sampling the coal seams was subordinated to the subject of the research project PBU, conducted in the years 2002-2005.

A total number of 35 rock samples underwent examination. Macropetrographic observation has been conducted together with qualitative and quantitative assessment of mineral composition.

In all samples presence of trace elements: $\mathrm{B}, \mathrm{Ba}, \mathrm{Cd}, \mathrm{Co}, \mathrm{Cr}, \mathrm{Cu}, \mathrm{Ni}, \mathrm{Pb}, \mathrm{Zn}, \mathrm{Mn}, \mathrm{Ag}, \mathrm{Sr}$, $\mathrm{Ge}, \mathrm{Be}, \mathrm{Li}, \mathrm{V}, \mathrm{As}$, and $\mathrm{Ga}$ has been found using an emission spectrometer AES with induction- coommanded plasma (ICP) of JY 2000 type (by XRF).

The objective of the research was to identify variability of trace element content in petrographic types of rocks. The influence of mineral composition on these contents was also subject to investigation. In order to achieve this goal, correlation associations have been investigated on the basis of research results of the correlation between trace elements content and presence of main minerals in the rocks. Types of rocks represented at least in 5 samples have been taken under consideration, meaning claystones, and sandy claystones, sideritic claystones, and mudstones.

The correlation was characterised after Krawczyk and Słomka (1986) by the values correlation coefficient $r$, defined as:

- very weak, for $r=0.3-0.5$

weak, for $r=0.5-0.7$

medium, for $r=0.7-0.9$

- strong, for $r>0.9$.

\section{Petrographic and mineral characteristics of barren rocks}

The rocks accompanying coal seams: roof, floor and bands in coal are represented mainly by claystones and sandy claystones ( 15 samples), rarely sideritic claystones ( 7 samples) and mudstones (5 samples), and only sporadically tonstein ( 2 samples), sideritic mudstones (3 samples), clayey siderite (1 sample), and sandstones ( 2 samples).

Claystones definitely dominated among coal seam barren rocks sampled in the northwestern part of USCB (Sośnica and Jadwiga coal mines). In the southwestern part of USCB (Rydułtowy, Marcel, Anna coal mines), sideritic claystones, mudstones, and sideritic mudstones occur the most frequently. In the roof of the 620 coal seam, in the south-western part of USCB above a relatively thin layer of mudstone, sandstone was also present. In the profile of the 610 coal seam there was a characteristic presence of tonstein as a band. Identified rocks exhibit macroscopic features typical to the petrogrphic types to which they belong. 


\subsection{Microscopic observations results}

Claystones, which were most numerously represented among the barren rocks demonstrated differentiated microtexture and mineral composition (Table 1).

Claystones from the roof, floor and bands of the 610 coal seam are the rocks of typically pelitic texture, in which, additionally to dominating amount of clayey minerals, significant admixtures of quartz are present, mainly pelitic, micas (biotite $>$ muscovite) with rare carbonates, mainly siderite. Moreover, they contain dispersed organic matter (coal).

In contrast, claystones coexisting with 620 coal seam differ from the described above from the 610 coal seam by the presence of coarsely grained quartz of dimension from $0.01-0.07 \mathrm{~mm}$ up to about $0,1 \mathrm{~mm}$, with small amount of pelitic quartz.

These claystones, due to large amount of coarser quartz grains, have been described as sandy claystones.

Presence of atypical claystones has been observed in the rocks accompanying the 630 coal seam. These are sideritic claystones of aleuritic-pelitic texture with admixtures of carbonate minerals (mainly siderite, rarely dolomite, calcite), most frequently with low content of quartz and micas. Characteristic for these rocks is the significant presence of illite in the base mass of clayey minerals.

Sideritic claystones are also accompanying the 620 coal seam. In relation to sideritic claystones from the 630 coal seam, they are characterized by a lower content of carbonate minerals and clearly pelitic texture.

Among clayey rocks accompanying the 610 coal seam fire clay, the so called tonstein, is present. Tonstein presents distinct genetic type of clayey rocks, created in a peat bog from pyroclastic material, i.e. volcanic ash (Dopita and Kralik 1977; Gabzdyl 1984, 1990; Ryszka and Gabzdyl 1986; Ryka and Maliszewska 1991; Łapot 1992; Bohor and Triplehorn 1993; Zhou et al. 2000; Admakin 1995, 2001; Dai et al. 2011).

These rocks are formed mainly by microcrystalline kaolinite, usually in the form of grainy, geloous aggregations. They sporadically form warm shaped pseudomorphs after feldspars. There are also present tabular forms of feldspars, differently kaolinitised muscovite flakes, bladed grains of pyroclastic quartz, and additionally terrigenous quartz. Isotropic chips of volcanic glass are visible locally. The texture of this tonstein is relatively heterogenic, pelitic-aleuritic, and almost psammitic locally.

All distinguished claystones types exhibited in their composition (including organic impurities) predominant content of clayey minerals (55.3-69.8\%) (Table 1). Quartz is present in amounts from a few up to a dozen or so percent. Similar content is exhibited by organic matter, less by micas, and in the least by carbonates (from a few up to less than $10 \%$ ). Sometimes the presence of small amounts of feldspars has been noticed.

Sandy claystones have been distinguished by the presence of quartz of the grain size $>0.01 \mathrm{~mm}$, however its content (like in case of the other mineral components) is variable in a similar range as in typical claystones. 
Table 1. The mineral composition of the accompanying rocks from the $610,620,630$ coal seams

Tabela 1. Skład mineralny skał towarzyszących pokładom węgla: 610, 620 i 630

The mineral composition of the claystone

\begin{tabular}{|c|c|c|c|c|c|c|c|}
\hline \multirow{3}{*}{$\begin{array}{l}\text { Number } \\
\text { of } \\
\text { samples }\end{array}$} & \multicolumn{7}{|c|}{ Components from - to $[\% \mathrm{vol}]$} \\
\hline & \multirow[b]{2}{*}{ quarz } & \multirow{2}{*}{$\begin{array}{c}\text { feldspars }+ \\
+ \text { clay } \\
\text { minerals }\end{array}$} & \multicolumn{2}{|c|}{ micas + clay minerals } & \multirow{2}{*}{$\begin{array}{c}\text { organic } \\
\text { matter (coal) }\end{array}$} & \multirow{2}{*}{$\begin{array}{l}\text { clayey } \\
\text { mass }\end{array}$} & \multirow[b]{2}{*}{ carbonates } \\
\hline & & & $\begin{array}{l}\text { muscovite, } \\
\text { sericite }\end{array}$ & $\begin{array}{l}\text { biotite, hydrobiotite, } \\
\text { chlorite }\end{array}$ & & & \\
\hline & \multicolumn{7}{|c|}{ Claystones and sandy claystones } \\
\hline \multirow[t]{2}{*}{15} & $8.1-15.4$ & $0-1.0$ & $1.4-3.8$ & $2.3-4.6$ & $15.6-19.7$ & $58.9-69.8$ & $0.4-6.0$ \\
\hline & \multicolumn{7}{|c|}{ Sideritic claystones } \\
\hline 7 & $6.2-11.6$ & - & $1.0-2.0$ & $2.1-4.4$ & $13.3-16.9$ & $55.3-59.1$ & $10.4-20.1$ \\
\hline
\end{tabular}

The mineral composition of the tonstein

\begin{tabular}{|c|c|c|c|c|c|c|c|}
\hline \multirow{3}{*}{$\begin{array}{l}\text { Number } \\
\text { of } \\
\text { samples }\end{array}$} & \multicolumn{7}{|c|}{ Components from - to $[\% \mathrm{vol}]$} \\
\hline & \multirow[b]{2}{*}{ quarz } & \multirow{2}{*}{$\begin{array}{l}\text { feldspars }+ \\
\quad+\text { clay } \\
\text { minerals }\end{array}$} & \multicolumn{2}{|c|}{ micas + clay minerals } & \multirow{2}{*}{$\begin{array}{c}\text { organic } \\
\text { matter } \\
(\text { coal })\end{array}$} & \multirow{2}{*}{$\begin{array}{c}\text { clayey mass, } \\
\text { cristaline kaolinite, } \\
\text { volcanic glass }\end{array}$} & \multirow[b]{2}{*}{ carbonates } \\
\hline & & & $\begin{array}{c}\text { muscovite, } \\
\text { sericite }\end{array}$ & $\begin{array}{c}\text { biotite, } \\
\text { hydrobiotite }\end{array}$ & & & \\
\hline 2 & $6.7-9.3$ & $16.2-17.0$ & \multicolumn{2}{|c|}{$21.1-22.3$} & $9.7-10.9$ & $41.8-43.6$ & $0.7-0.9$ \\
\hline
\end{tabular}

The mineral composition of the mudstones, sideritic mudstones and sandstones

\begin{tabular}{|c|c|c|c|c|c|c|c|c|c|c|c|}
\hline \multirow{2}{*}{$\begin{array}{l}\text { Number } \\
\text { of } \\
\text { samples }\end{array}$} & \multicolumn{8}{|c|}{ Components from - to $[\% \mathrm{vol}]$} & \multicolumn{3}{|c|}{ Binder } \\
\hline & Q & Ort & Pl & Msc & $\mathrm{Bt}$ & Agg. rock & $\begin{array}{c}\text { Heavy } \\
\text { minerals }\end{array}$ & $\begin{array}{c}\text { organic } \\
\text { matter }\end{array}$ & clayey & silica & carbonate \\
\hline & \multicolumn{11}{|c|}{ Mudstones } \\
\hline \multirow[t]{2}{*}{5} & $16.2-21.1$ & - & $1.3-1.9$ & $2.7-7.1$ & $9.4-11.6$ & $0.6-2.7$ & $0-0.3$ & $12.1-16.1$ & $42.8-46.1$ & $1.2-4.2$ & $0.2-6.6$ \\
\hline & \multicolumn{11}{|c|}{ Sideritic mudstones } \\
\hline \multirow[t]{2}{*}{3} & $19.8-24.4$ & - & $1.1-1.9$ & $4.2-8.4$ & $7.2-16.2$ & $3.1-4.9$ & $0-0.2$ & $8.0-11.8$ & $17.9-20.2$ & $1.6-2.5$ & $20.3-23.1$ \\
\hline & \multicolumn{11}{|c|}{ Sandstones } \\
\hline 2 & $43.9-48.2$ & $3.9-4.0$ & $6.1-6.4$ & $3.1-3.6$ & $2.0-2.1$ & $5.5-6.2$ & $0.4-0.6$ & $7.2-7.6$ & $2.4-4.1$ & $7.5-7.8$ & $13.1-14.3$ \\
\hline
\end{tabular}

$\mathrm{Q}$ - guarz, ort - ortoclases, Pl - plagioclases, Msc - muscovite, Bt - biotite, Aggr rock - rock aggregates.

The mineral composition of the clayey siderite

\begin{tabular}{|c|c|c|c|c|c|}
\hline \multirow{2}{*}{ Number of samples } & \multicolumn{5}{|c|}{ Components from - to [\% vol] } \\
\cline { 2 - 6 } & quarz & siderite & clay minerals & organic matter & kalcite/dolomite \\
\hline \multirow{2}{*}{1} & 4.1 & 56.7 & 22.2 & 7.6 & 9.3 \\
\hline
\end{tabular}


By contrast, sideritic claystones are characterized by a high content of carbonates (10.4-20.1\%) represented mainly by siderites, in smaller amount by dolomite, and an even smaller content of micas and quartz.

In the mineral composition of tonstein samples attention should be paid to smaller content of clayey minerals due to the high content of micas and feldspars in relation to claystones (Table 1).

The results of quantitative and qualitative analysis of claystones mineral composition may be influenced by some minor errors due to small grain size, however they confirmed their petrographic-mineralogical differentiation after being observed both macroscopically and microscopically.

Mudstones are characterised by aleuritic texture, a layered structure emphasized by the presence of smudges, laminas and tiny lenses of coal and being laid parallel to each other.

Aggregated material is represented mainly by quartz and micas (dominantly biotite). Sometimes grains of feldspars are present (plagioclases) as well as sparse fragments of quartzite.

In variable amounts carbonates are present as crystalline aggregations of siderite.

Characteristic for these rocks is the presence of large amounts of clayey or clayey-silica binder of a basic mass type.

Sideritic mudstones, in relation to typical mudstones, are characterised by clearly smaller amount of clayey binder (porous), by the dominance of sideritic binder and higher content of aggregated material (quartz, micas and rock aggregates).

Additionally to mudstones and sideritic mudstones, between the bands from the 630 coal seam in "Rydułtowy" coal mine, a sample of clayey siderite has been distinguished with a clearly dominating content of siderite. Also significant is the presence of clayey minerals in the fact of sparse content of quartz and organic matter (coal) and also calcite and dolomite.

Sandstones are represented in samples collected from the roof of the 620 coal seam at the "Rydultowy" coal mine. These sandstones are fine grained, with more than half of the composition being quartz. Between other minerals sparse grains of feldspars, micas, and rock aggregates can be observed. It also contains small amounts of a binder of clayey-silica-carbonate character.

\subsection{Chemical composition of rocks}

Samples of barren rocks coexisting with coal in seams demonstrate rather high differentiation of chemical component content in relation to the petrographic types, which they represent, and also within the same variety.

The chemical composition of claystones, which is described together with sandy claystones, is characterised by the dominating presence of $\mathrm{SiO}_{2}$ among all determined components (Table 2). The content of $\mathrm{SiO}_{2}$ is highly differentiated, expressed by the highest standard deviation $\mathrm{s}_{\mathrm{d}}$ (4.49) from its average content, in relation to the other chemical components. 
The second important component of claystones is $\mathrm{Al}_{2} \mathrm{O}_{3}$, whose high content demonstrates smaller differentiation and is characterised by a smaller value of standard deviation $\left(\mathrm{s}_{\mathrm{d}}=1.11\right)$ from its average value.

From the $\mathrm{SiO}_{2}$ to $\mathrm{Al}_{2} \mathrm{O}_{3}$ ratio results, the considered claystones are significantly differentiated by the presence of free silica not bound with $\mathrm{Al}_{2} \mathrm{O}_{3}$. Free silica is occurring in a form of terrigenous quartz or authigenic forms of $\mathrm{SiO}_{2}$ (opal and chalcedony), which can be microscopically observed.

Considerably differentiated content also exhibits loss of ignition $\left(s_{d}=3.47\right), \mathrm{Fe}_{2} \mathrm{O}_{3}$ ( $\mathrm{s}_{\mathrm{d}}=2.93$ ), and $\mathrm{FeO}, \mathrm{P}_{2} \mathrm{O}_{5}$ and $\mathrm{K}_{2} \mathrm{O}$ contents with standard deviation values of about 1.0. Other chemical components, i.e. $\mathrm{CaO}, \mathrm{MgO}, \mathrm{H}_{2} \mathrm{O}, \mathrm{MnO}, \mathrm{S}_{\mathrm{p}}$, exhibited small differentiation of their content in claystones and small values of standard deviation $\mathrm{s}_{\mathrm{d}}$.

The chemical composition of analysed claystones, despite being presented above the variability in the content of certain components, is typical for claystones coexisting with coals seams in USCB (Kuhl 1955; Gabzdyl 1969; Chodyniecka and Wilk 1979; Trela and Tabor 1984; Adamczyk 1998).

Sideritic claystones demonstrate distinct chemical composition in relation to the composition of the claystones described above.

These rocks, when compared with claystones, are characterised by a lower content of $\mathrm{Al}_{2} \mathrm{O}_{3}$ by similar $\mathrm{SiO}_{2}$ content (Table 2). Thus, the value of the $\mathrm{SiO}_{2} / \mathrm{Al}_{2} \mathrm{O}_{3}$ ratio is high (max. 4.45). It may be concluded from the value of this ratio that only a part of $\mathrm{SiO}_{2}$ relates to the clayey minerals (kaolinite, illite), the rest part of it forms free silica, despite relatively low content of microscopically determinable quartz.

In sideritic claystones, with consistently high amount of siderite, quite a bit higher is the $\mathrm{FeO}$ content. Simultaneously, the content of $\mathrm{Fe}_{2} \mathrm{O}_{3}$ is decreased. Higher and more differentiated than in claystones is the content of $\mathrm{CaO}$ and often also $\mathrm{MgO}$, which results from the presence of dolomite, which was visible under the microscope.

The presence of $\mathrm{Na}_{2} \mathrm{O}, \mathrm{K}_{2} \mathrm{O}, \mathrm{S}_{\mathrm{p}}$ and $\mathrm{P}_{2} \mathrm{O}_{5}$ is near to the values obtained in the case of analysed claystones.

Almost all chemical components, except $\mathrm{CaO}$ and $\mathrm{MgO}$ measured in sideritic claystones, exhibit smaller differentiation of content in relation to claystones, which is denoted by generally small values of standard deviations (Table 2).

Tonstein distinguishes from the rest of analysed rocks with the highest content of $\mathrm{Al}_{2} \mathrm{O}_{3}$ and the lowest value of $\mathrm{SiO}_{2}$ to $\mathrm{Al}_{2} \mathrm{O}_{3}$ ratio (2.48 and 2.91) (Table 2), which evidences high content of kaolinite in these rocks. The content of the other chemical components does not differ from their content in the already described clayey rocks.

The chemical composition of mudstones distinguishes them from claystones with a higher amount of silica $\mathrm{SiO}_{2}$ via a small and undifferentiated (low $\mathrm{s}_{\mathrm{d}}$ values) amount of $\mathrm{Al}_{2} \mathrm{O}_{3}$ (Table 2).

It points at a rather high content of clayey minerals in mudstones as per their mineral composition. For this reason, according to Shepards' classification (1973), these rocks belong to clayey mudstones (siltstones) 
Kokowska-Pawłowska 2015 / Gospodarka Surowcami Mineralnymi - Mineral Resources Management 31(2), 73-92

\begin{tabular}{|c|c|c|c|c|c|c|c|c|c|c|}
\hline & 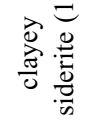 & 宸 & \pm & $\begin{array}{l}\text { ta } \\
\text { bे }\end{array}$ & 吕 & 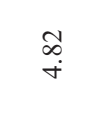 & 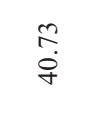 & $\vec{i}$ & $\stackrel{\infty}{\stackrel{\infty}{i}}$ & ָัָ \\
\hline & త & 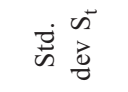 & 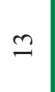 & तु तે & $\stackrel{\Re}{ت}$ & है & $\cong$ & ¿.0. & 啇 & $\stackrel{\infty}{\infty}$ \\
\hline & 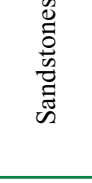 & 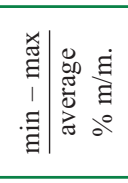 & $\simeq$ & 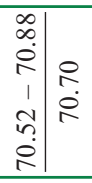 & 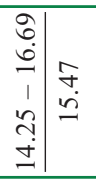 & 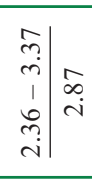 & 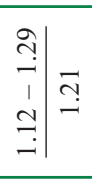 & \begin{tabular}{l|l} 
& 0 \\
0 & 0 \\
$\vdots$ & 0 \\
0 & 0 \\
0 & 0 \\
0
\end{tabular} & 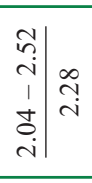 & 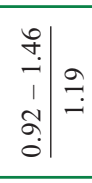 \\
\hline & $\begin{array}{l}\text { on } \\
\text { : }\end{array}$ & 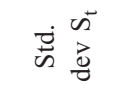 & $=$ & $\overline{\mathrm{o}}$ & à & $\stackrel{\mathcal{F}}{-}$ & gे & $\stackrel{8}{0}$ & ?f & $\hat{n}$ \\
\hline & 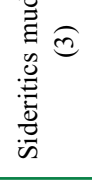 & 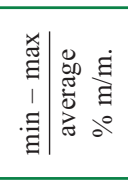 & 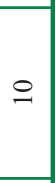 & 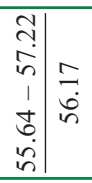 & 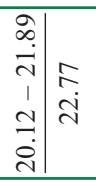 & 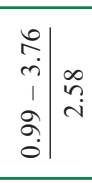 & 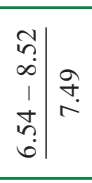 & 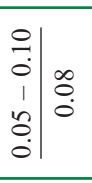 & 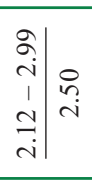 & 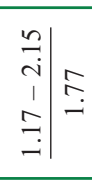 \\
\hline & $\sqrt{6}$ & 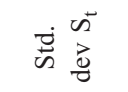 & $a$ & ถે & o. & ơ & : & $\stackrel{8}{0}$ & $\begin{array}{c}\infty \\
\stackrel{\infty}{0} \\
0\end{array}$ & fै. \\
\hline & 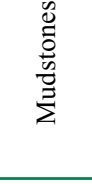 & 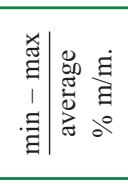 & $\infty$ & 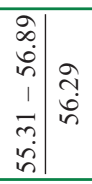 & 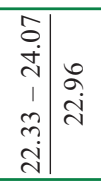 & 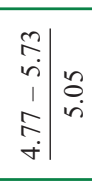 & 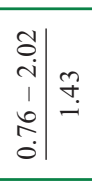 & 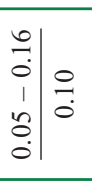 & 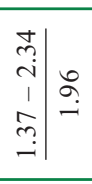 & 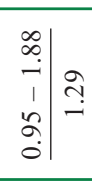 \\
\hline & $\widehat{d}$ & 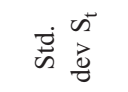 & $r$ & $\tilde{\tilde{n}}$ & $\stackrel{\widehat{\sigma}}{-}$ & 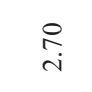 & $\begin{array}{l}n \\
n \\
0\end{array}$ & $\stackrel{8}{0}$ & $\begin{array}{c}\infty \\
\infty \\
\infty \\
0\end{array}$ & $\stackrel{\infty}{\Im ి ~}$ \\
\hline $\begin{array}{l}\stackrel{8}{6} \\
\frac{\pi j}{50}\end{array}$ & 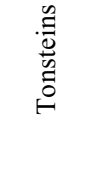 & 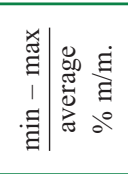 & 0 & 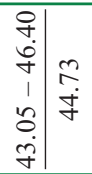 & 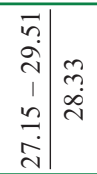 & 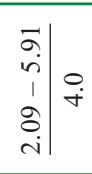 & 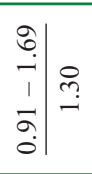 & 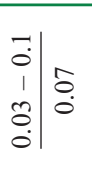 & 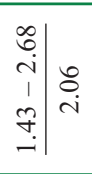 & 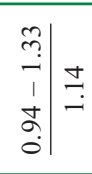 \\
\hline $\bar{\delta}$ & 总 & 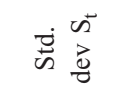 & in & 芯 & f̊ & $\stackrel{\cong}{\leftrightarrows}$ & 荾 & $\stackrel{8}{\circ}$ & gे & $\stackrel{\cong}{\leftrightarrows}$ \\
\hline 常 & 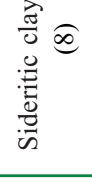 & 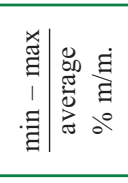 & + & 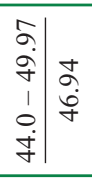 & 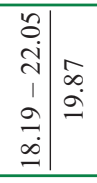 & 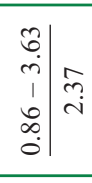 & 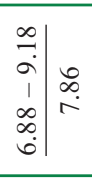 & 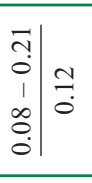 & 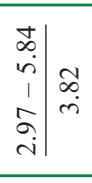 & 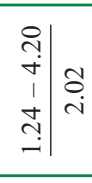 \\
\hline & 昰氙 & 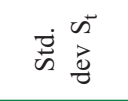 & $m$ & $\underset{+}{q}$ & $\exists$ & & $\stackrel{\bullet}{-}$ & $\stackrel{n}{0}$ & $\hat{n}$ & రీ \\
\hline 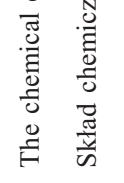 & 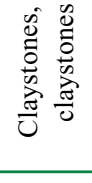 & 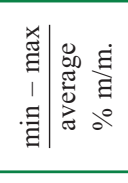 & $\sim$ & 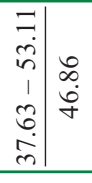 & 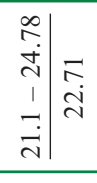 & 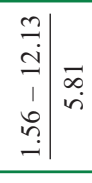 & 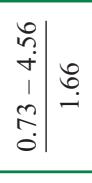 & 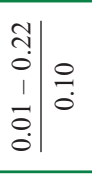 & 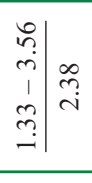 & 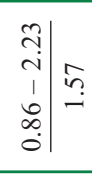 \\
\hline 荵 & & & - & $\overbrace{}^{2}$ & 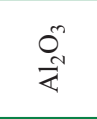 & 党 & 号 & $\stackrel{ᄋ}{\sum}$ & 苂 & $\sum_{z}^{\infty}$ \\
\hline
\end{tabular}




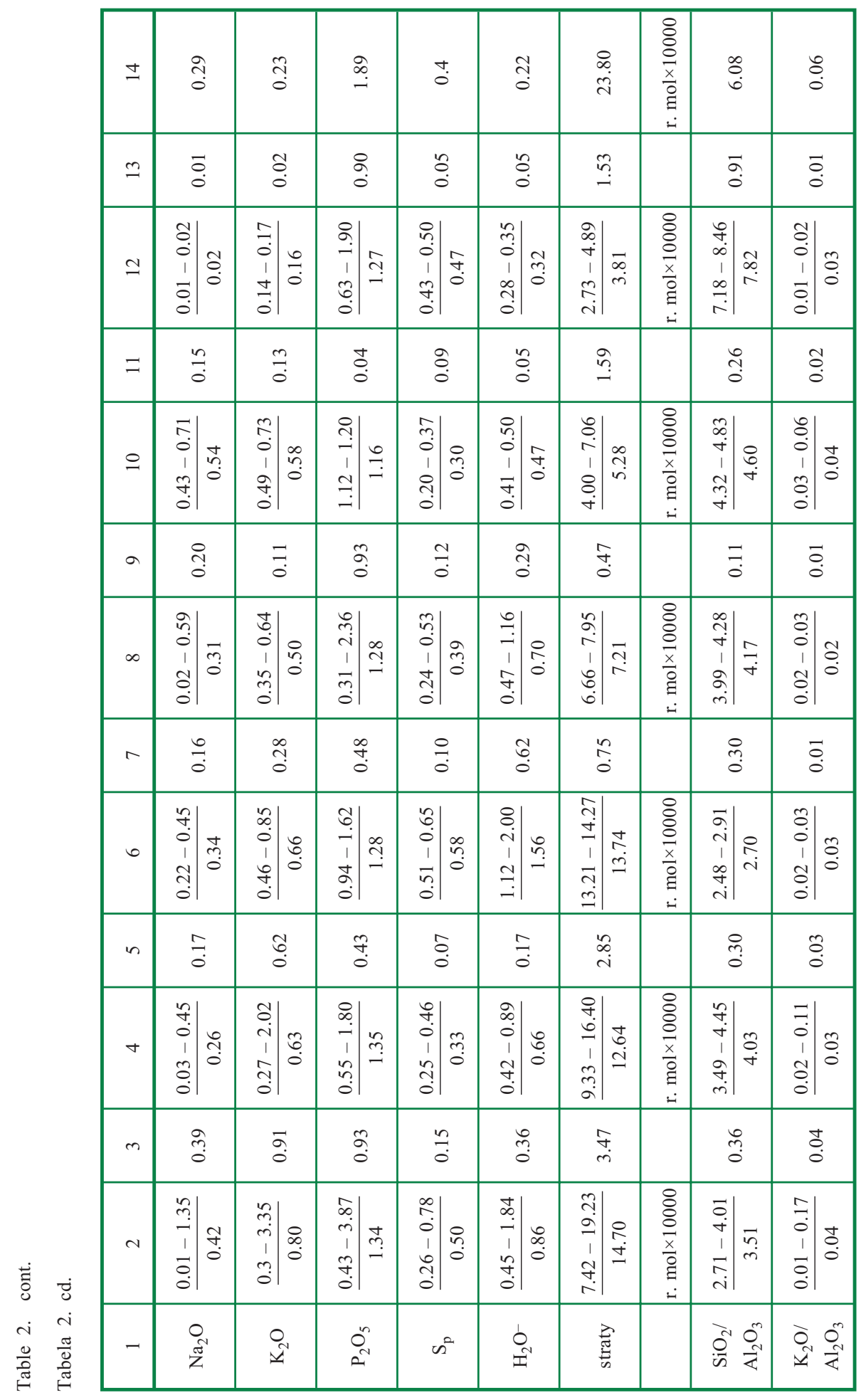


Values of $\mathrm{SiO}_{2} / \mathrm{Al}_{2} \mathrm{O}_{3}$ ratio range between 3.99 and 4.28.

Moreover, mudstones demonstrate quite high, but undifferentiated $\mathrm{Fe}_{2} \mathrm{O}_{3}$ content, and predominantly low $\mathrm{FeO}$ content. These components are partially related to illite, biotite, and siderite. Relatively low content was demonstrated by $\mathrm{CaO}, \mathrm{MgO}, \mathrm{Na}_{2} \mathrm{O}_{3}, \mathrm{~K}_{2} \mathrm{O}, \mathrm{S}_{\mathrm{p}}{ }^{\mathrm{d}}$, which was variable in a similar range as in claystones.

Sideritic mudstones demonstrated a content of $\mathrm{SiO}_{2}$ similar to previously described mudstones, but much lower content of $\mathrm{Al}_{2} \mathrm{O}_{3}$ (Table 2). It results from a higher content of quartz and clearly lower content of clayey minerals. These rocks are distinguished by high content of $\mathrm{FeO}$, related to the presence of siderite in their composition. Increased contents of $\mathrm{FeO}$ is not accompanied by elevated amounts of $\mathrm{CaO}$ and $\mathrm{MgO}$ as it was observed in sideritic claystones. The other components: $\mathrm{Na}_{2} \mathrm{O}, \mathrm{K}_{2} \mathrm{O}, \mathrm{P}_{2} \mathrm{O}_{5}$, and $\mathrm{S}_{\mathrm{p}}$ do not differ in terms of content with other types of rocks.

Clayey siderite is characterised by the dominant presence of $\mathrm{FeO}(40.73 \% \mathrm{~m} / \mathrm{m})$ in the chemical composition (Table 2). Contents of $\mathrm{SiO}_{2}$ and $\mathrm{Al}_{2} \mathrm{O}_{3}$ as well as $\mathrm{SiO}_{2} / \mathrm{Al}_{2} \mathrm{O}_{3}$ ratio value (6.08) indicate high amounts of free silica and low content of clayey minerals. It should be noticed that the large part of $\mathrm{SiO}_{2}$ is present in a form of amorphous silica, which proves low content of quartz being observed microscopically.

Sandstones are characterized by high $\mathrm{SiO}_{2}$ content with relatively low content of $\mathrm{Al}_{2} \mathrm{O}_{3}$ in relation to other considered rocks (Table 2). In their chemical composition there is characteristic low amount of iron $\left(\mathrm{Fe}_{2} \mathrm{O}_{3}\right.$ and $\left.\mathrm{FeO}\right)$ and alkalis $\left(\mathrm{Na}_{2} \mathrm{O}\right.$ and $\left.\mathrm{K}_{2} \mathrm{O}\right)$.

A common feature of rock accompanying coal in analysed coal seams is low content of pyritic sulphur $\mathrm{S}_{\mathrm{p}}$, whose average content reaches a maximum of $0.78 \% \mathrm{~m} / \mathrm{m}$, and for particular samples often is lower than $0.5 \% \mathrm{~m} / \mathrm{m}$.

Attention should be given to the increased content of $\mathrm{P}_{2} \mathrm{O}_{5}$, the average value of which in considered samples takes values from 1.16 up to $1.34 \% \mathrm{~m} / \mathrm{m}$ and at maximum reaches $3.87 \% \mathrm{~m} / \mathrm{m}$ (claystones). Analysed claystones did not exhibit presence of apatite, possibly due to the fact that $\mathrm{P}_{2} \mathrm{O}_{5}$ is an amorphous component of cellophane and other amorphous compounds of phosphor with iron, aluminium and calcium (Gabzdyl and Ryszka 1955). It can be also assumed that this component originates from the decomposition of organic matter, which may be concluded from significant admixtures of coal accompanying the presence of $\mathrm{P}_{2} \mathrm{O}_{5}$ in all considered types of rocks.

Similarly high amounts of $\mathrm{P}_{2} \mathrm{O}_{5}$ were observed in the rocks from the bands in coal seams by Gabzdyl and Ryszka (1955). High $\mathrm{P}_{2} \mathrm{O}_{5}$ content (max. $\left.8.46 \% \mathrm{~m} / \mathrm{m}\right)$ was also observed in a tonstein from 349 coal seam by Gorol (1996).

\section{Presence of trace elements in the barren rocks}

Trace elements in the analysed petrographic variety of barren rocks demonstrated characteristic differentiation and variable content. Almost all types of rocks (except tonstein) exhibited dominant but variable presence of barium $\mathrm{Ba}$ and vanadium $\mathrm{V}$, by significant 
content of $\mathrm{Zn}, \mathrm{Mn}, \mathrm{Pb}, \mathrm{Cu}$, and $\mathrm{Ni}$. Analysis of trace elements content differentiation in petrographic variety of barren rocks has been conducted. The method was that for each measured element arithmetic means have been calculated from the contents in samples, which represented distinguished petrographic types of rocks. The results have been shown in Fig. 1.

Claystones and sandy claystones are characterised by the highest average content of many elements, like $\mathrm{V}, \mathrm{Ba}, \mathrm{Cr}, \mathrm{Be}, \mathrm{Cd}$, in relation to the other petrographic variety of barren rocks.

According to the data presented in literature, in sedimentary rocks these elements are most of all associated with clayey rocks (Polański 1988; Dill et al. 1991; Ferm et al. 2002; Migaszewski and Gałuszka 2003; Ward et al. 2005; Yarali et al. 2008). Cd is an exception here, for while it was rarely identified in sedimentary rocks it is associated mainly with the presence of sulphides (mainly $\mathrm{ZnS}$ ).

High contents in claystones also demonstrate such elements as $\mathrm{Mn}, \mathrm{Zn}, \mathrm{Cu}$, As, and $\mathrm{Li}$. The other assessed elements: $\mathrm{Ni}, \mathrm{Pb}, \mathrm{Ga}, \mathrm{Ge}, \mathrm{Co}, \mathrm{Sr}$, and $\mathrm{Ag}$ are mainly characterised by lower content than in other types of rocks.

Minimal contents in claystones and other analysed rocks represent: $\mathrm{Cd}, \mathrm{Ag}$, and $\mathrm{Sr}$.

Sideritic claystones are distinguished by the presence of only two elements, $\mathrm{Ge}$ and $\mathrm{Cr}$, whose contents are nearing their maximal value being found in claystones $(\mathrm{Ge})$ and sandstones $(\mathrm{Cr})$ respectively.

An average amount of numerous elements like $\mathrm{Be}, \mathrm{Ni}, \mathrm{Ga}, \mathrm{Ag}, \mathrm{Zn}$, and $\mathrm{Mn}$ in sideritic claystones is similar to their contents occurring in claystones; elements: $\mathrm{Co}, \mathrm{Li}, \mathrm{Pb}, \mathrm{Cu}$, and $\mathrm{Zn}$ are minimal. It seems that the decreased content of numerous elements in sideritic claystones originates from a different geochemical character of the sedimentation environment and diagenesis of these rocks (Polański 1988).

Tonstein demonstrates the highest amount of $\mathrm{Zn}$ and higher content of $\mathrm{Ga}, \mathrm{Co}$, and $\mathrm{Ni}$ than in claystones. High Ga content may be justified by a high amount of Al in these rocks, which may diadochically substite each other.

Increased contents of $\mathrm{Co}, \mathrm{Ni}$, and $\mathrm{Zn}$ may result from increased, in relation to claystones, content of $\mathrm{Fe}$ for which these elements demonstrate strong diadochical affinity.

Mudstones exhibit the highest average content of only two elements, Ni and Co among considered rocks, as well as high and close to the maximum contents of $\mathrm{Zn}, \mathrm{Cr}, \mathrm{Cu}, \mathrm{Be}$. High amount of such elements as $\mathrm{Co}, \mathrm{Zn}, \mathrm{Ni}$, and $\mathrm{Cr}$ may be associated with high content of $\mathrm{Fe}$ in mudstones.

Compared with claystones and sandstones, mudstones demonstrate lower average content of many elements, like As, Ga, Ba, Ge, Ag and Sr. Decreased content of such elements like $\mathrm{Ge}, \mathrm{Ga}$ and $\mathrm{Sr}$ is difficult to explain while these elements are genetically associated with main minerals in mudstones, i.e. quartz, feldspars, and clayey minerals.

Sideritic mudstones are characterised by the highest average amounts of elements $\mathrm{Pb}$ and $\mathrm{Mn}$ and significant content of $\mathrm{Ge}, \mathrm{Li}, \mathrm{Cr}, \mathrm{Ni}, \mathrm{Cd}, \mathrm{Sr}, \mathrm{Ba}$, and $\mathrm{Zn}$, in relation to the rest of analysed rocks. Low contents exhibited following elements: $\mathrm{Ga}, \mathrm{Cu}, \mathrm{As}, \mathrm{Co}, \mathrm{Be}$, and $\mathrm{Ag}$. 

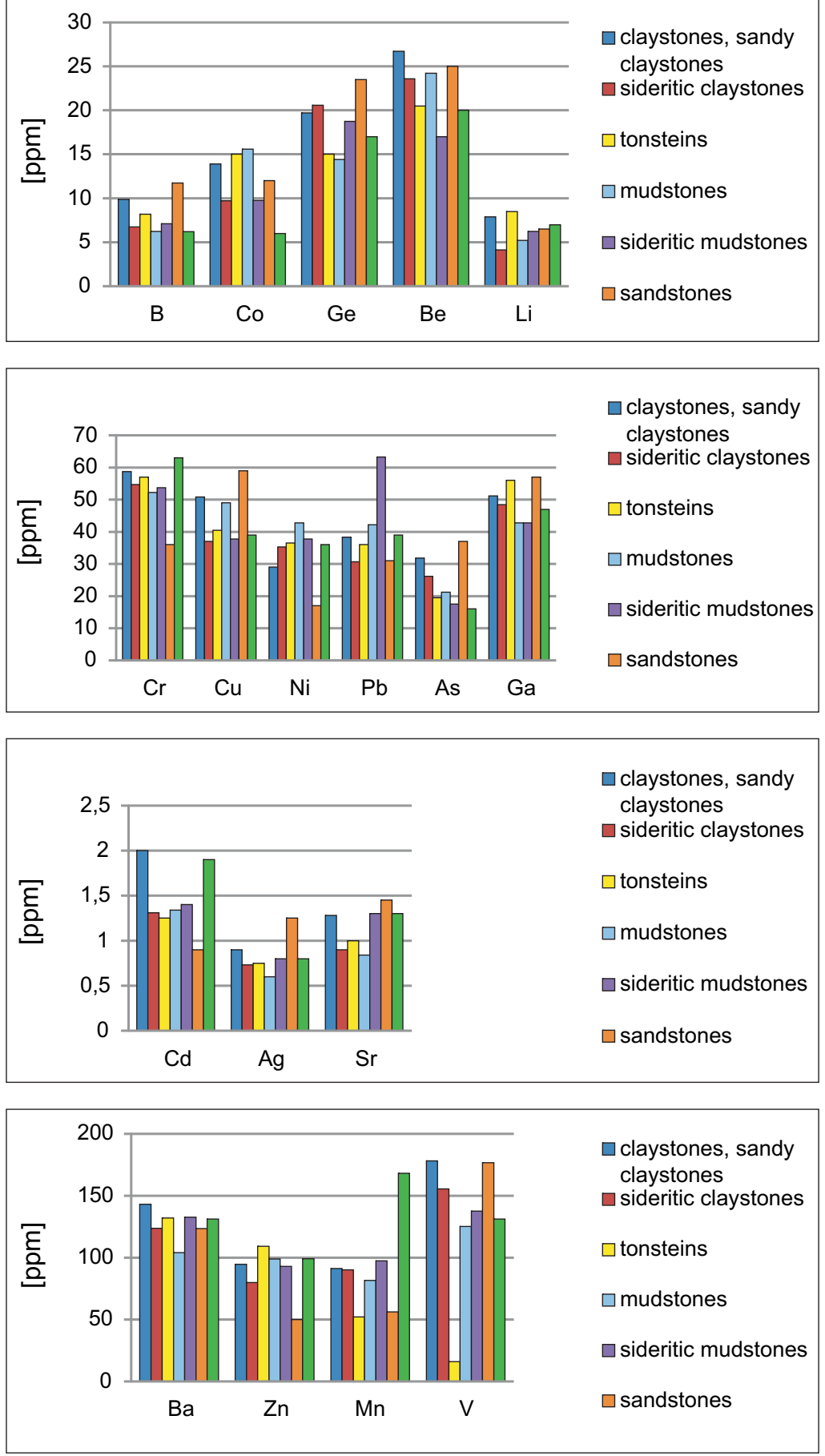

Fig. 2. The trace elements average content in selected variety rocks

Rys. 2. Średnia zawartość pierwiastków śladowych w wybranych odmianach skał 
It should be noted that the average contents of numerous elements $(\mathrm{Ba}, \mathrm{Cr}, \mathrm{Cu}, \mathrm{Ni}, \mathrm{B}$, $\mathrm{Co}, \mathrm{Ge}, \mathrm{Cd}, \mathrm{Ag}$ ) in sideritic mudstones are close to the average contents of these elements in sideritic claystones. It may suggest that these rocks were created in similar geochemical conditions.

Clayey siderite was present in a single sample of a band in the 630 coal mine, where sideritic mudstones have also been present. The composition of trace elements in clayey siderite is distinguished by high content of $\mathrm{Mn}$ and $\mathrm{Ga}$ and lower content of $\mathrm{Pb}$ than sideritic mudstones. The other elements observed in clayey siderite demonstrated similar contents as in sideritic mudstones.

Sandstones are distinguished, among analysed rocks, by dominating average content of the largest group of elements, namely $\mathrm{Cu}, \mathrm{As}, \mathrm{Ga}, \mathrm{B}, \mathrm{Ge}, \mathrm{Ag}$, and $\mathrm{Sr}$. Also high is the content of $\mathrm{V}$, which is close to its maximal values observed in claystones. Elements exhibiting minimal average content in sandstones are $\mathrm{Cr}, \mathrm{Ni}, \mathrm{Pb}, \mathrm{Cd}, \mathrm{Zn}$, and $\mathrm{Mn}$.

The above described characteristics of the differentiation of average contents of trace elements between petrographic varieties of barren rocks shows that it results mainly from differentiated genesis of the rocks, expressed also in the differentiated mineral composition of these rocks.

This differentiation is probably influenced by the geochemical environment, where the rocks underwent later, post-sedimentation dia- and epigenetic processes which explains the presence of anomalies of the contents of several elements in analysed samples (Kabata-Pendias and Pendias 1999).

\section{Correlative dependence of mineral composition of rocks on the trace elements content}

The results of correlative relations research between trace elements contents and mineral composition of rocks do not allow explicit determination of this dependence (Tables 3, 4).

In claystones the most numerous group of elements exhibited low affinity with organic matter (coal), whose content in these rocks is variable in the range from 15.6 to $19.7 \%$.

The correlation coefficient factors are in most cases low $(\mathrm{r}<0.5)$ and signalize weak correlation of such elements as $\mathrm{Cr}, \mathrm{Pb}, \mathrm{Ag}, \mathrm{Sr}, \mathrm{Be}, \mathrm{Li}, \mathrm{V}, \mathrm{As}$, and $\mathrm{Ga}$ with organic matter. Only few elements: $\mathrm{B}, \mathrm{Ni}$, and $\mathrm{Mn}$ are characterized by better correlation with organic matter, which is expressed by higher values of $r(r>0.6)$.

Evident correlation $(r>0.5)$ with clayey minerals exhibit such elements as $\mathrm{Pb}$ and $\mathrm{Li}$. Certain elements $(\mathrm{Cr}, \mathrm{Ag}, \mathrm{Sr}, \mathrm{V}, \mathrm{As})$ are characterised by better correlation $(\mathrm{r}>0.5)$ with carbonates than organic matter. Elements $\mathrm{Pb}, \mathrm{Ga}$, and $\mathrm{Cd}$ exhibited evident correlation with muscovite, although elements $\mathrm{Zn}, \mathrm{Ni}$, and $\mathrm{Cd}$ also correlate with biotite. Such elements as $\mathrm{Cr}$, $\mathrm{Mn}, \mathrm{Be}$, and $\mathrm{V}$ exhibit evident correlation $(\mathrm{r}>0.5)$ with quartz.

In sideritic claystones, similarly as in claystones, elements exhibiting positive correlation with organic matter make up the most numerous group. These elements include B, Ag, 
Table 3. The correlation coefficient ( $r$ ) of the trace elements in claystones with main minerals components

Tabela 3. Współczynnik korelacji (r) pierwiastków śladowych w iłowcach z głównymi składnikami mineralnymi

\begin{tabular}{|c|c|c|c|c|c|c|c|c|c|c|c|c|}
\hline & \multicolumn{6}{|c|}{ Claystones, sandy claystones } & \multicolumn{6}{|c|}{ Sideritic claystones } \\
\hline & 1 & 2 & 3 & 4 & 5 & 6 & 1 & 2 & 3 & 4 & 5 & 6 \\
\hline $\mathrm{B}$ & 0.21 & -0.12 & -0.13 & -0.03 & 0.18 & 0.63 & -0.05 & -0.93 & 0.97 & -0.87 & -0.52 & 0.93 \\
\hline $\mathrm{Ba}$ & -0.09 & 0.33 & 0.00 & 0.44 & -0.28 & 0.04 & -0.04 & -0.92 & 0.97 & -0.87 & -0.53 & 0.80 \\
\hline $\mathrm{Cd}$ & -0.85 & 0.46 & 0.48 & 0.87 & -0.91 & -0.26 & 0.21 & 0.97 & -1 & 0.78 & 0.38 & 0.83 \\
\hline $\mathrm{Co}$ & -0.42 & -0.23 & 0.2 & -0.1 & -0.09 & -0.20 & 0.16 & 0.96 & -0.99 & 0.81 & 0.43 & -0.53 \\
\hline $\mathrm{Cr}$ & 0.53 & -0.95 & 0.22 & -0.58 & 0.57 & 0.27 & 0.1 & 0.95 & -0.98 & 0.84 & 0.48 & -0.33 \\
\hline $\mathrm{Cu}$ & -0.04 & -0.12 & -0.69 & -0.62 & 0.59 & 0.01 & -0.11 & -0.95 & 0.98 & -0.83 & -0.47 & 0.22 \\
\hline $\mathrm{Ni}$ & -0.53 & -0.13 & 0.52 & 0.27 & -0.44 & 0.74 & 0.14 & 0.96 & -0.99 & 0.82 & 0.44 & -0.89 \\
\hline $\mathrm{Pb}$ & -0.2 & 0.76 & -0.21 & 0.52 & -0.4 & 0.30 & 0.13 & -0.84 & 0.91 & -0.94 & -0.67 & -0.42 \\
\hline $\mathrm{Zn}$ & -0.65 & 0.15 & 0.65 & 0.78 & -0.8 & -0.34 & -0.02 & -0.92 & 0.96 & -0.88 & -0.55 & -0.83 \\
\hline $\mathrm{Mn}$ & 0.69 & -0.88 & 0.46 & -0.28 & 0.37 & 0.59 & -0.19 & 0.81 & -0.89 & 0.96 & 0.71 & -0.02 \\
\hline $\mathrm{Ag}$ & 0.2 & 0.22 & -0.98 & -0.64 & 0.67 & 0.40 & -0.08 & -0.94 & 0.98 & -0.85 & -0.5 & 0.78 \\
\hline $\mathrm{Sr}$ & 0.1 & 0.25 & -0.97 & -0.58 & 0.61 & 0.13 & 0.07 & -0.88 & 0.94 & -0.92 & -0.62 & 0.20 \\
\hline $\mathrm{Ge}$ & 0.15 & 0.36 & -0.97 & -0.52 & 0.56 & -0.25 & 0.67 & -0.39 & 0.53 & -0.97 & -0.97 & 0.54 \\
\hline $\mathrm{Be}$ & 0.62 & -0.14 & 0.21 & -0.04 & 0.11 & 0.43 & 0.56 & 0.99 & -0.95 & 0.48 & 0 & 0.81 \\
\hline $\mathrm{Li}$ & -0.7 & 0.38 & 0.24 & 0.67 & -0.65 & 0.31 & 0.47 & 1 & -0.98 & 0.58 & 0.11 & 0.76 \\
\hline $\mathrm{V}$ & 0.56 & -0.4 & -0.52 & -0.68 & 0.78 & 0.22 & 0.14 & -0.84 & 0.91 & -0.94 & -0.67 & 0.89 \\
\hline As & 0.14 & -0.05 & -0.85 & -0.72 & 0.72 & 0.45 & -0.22 & -0.98 & 1 & -0.77 & -0.37 & 0.74 \\
\hline $\mathrm{Ga}$ & -0.05 & 0.65 & -0.58 & 0.13 & -0.01 & 0.40 & 0.97 & 0.17 & -0.02 & -0.67 & -0.94 & 0.20 \\
\hline
\end{tabular}

1 - quarz, 2 - muscovite/sericite, 3 - biotite/hydrobiotite/chlorite, 4 - clayey mass/clayem binder, 5 - siderite/siderite mass, 6 - organic matter

$\mathrm{Be}, \mathrm{Li}, \mathrm{V}, \mathrm{As}$, and $\mathrm{Ga}$, and additionally $\mathrm{Ba}, \mathrm{Cd}$, and $\mathrm{Ge}$. These elements are characterized by correlation coefficient values $r>0.5$, often $r>0.7$.

Numerous elements also exhibit evident affinity with clayey minerals. This group includes $\mathrm{Cd}, \mathrm{Co}, \mathrm{Cr}, \mathrm{Pb}, \mathrm{Ni}, \mathrm{Mn}, \mathrm{Be}$, and $\mathrm{Li}$. Some of these elements, like $\mathrm{Cd}, \mathrm{Co}, \mathrm{Cr}, \mathrm{Pb}$, and $\mathrm{Mn}$ also exhibit a weak affinity with carbonate minerals.

The high correlation coefficients $\mathrm{r}>0.9$ with muscovite and siderite of elements $\mathrm{Li}, \mathrm{Cr}, \mathrm{Ni}, \mathrm{Co}, \mathrm{Cd}$, and $\mathrm{Be}$ are remarkable. Numerous are also elements of high (B, Ba, $\mathrm{Cu}, \mathrm{Zn}, \mathrm{Pb}, \mathrm{Ag}, \mathrm{Sr}, \mathrm{V}$, and $\mathrm{As})$ or clear $(\mathrm{Ge}, \mathrm{B}$, and $\mathrm{Li})$ correlation with the presence of biotite.

In mudstones only a few elements expressed positive correlation with the presence of some mineral components. 
Correlation coefficient values are most frequently very low $(\mathrm{r}<0.3)$ and low $(\mathrm{r}=0.3-$ $-0.5)$, and only sporadically higher $(r>0.5)$, pointing at evident correlation (Table 4).

The highest values of the correlation coefficient occur in case of dependence elements $\mathrm{Ni}$ and Co content on the presence of organic matter. Besides the mentioned elements, the presence of organic matter also correlates with $\mathrm{Cd}, \mathrm{Zn}$, and Li. Lower values of the coefficient characterize correlation of element $\mathrm{Cd}$ with light and dark micas and also elements $\mathrm{V}$ and $\mathrm{Ag}$ with dark micas and chlorite.

Elements $\mathrm{B}, \mathrm{Ba}, \mathrm{Pb}, \mathrm{Li}$ exhibited weak and very weak affinity with clayey minerals. Element $\mathrm{Mn}$ exhibits weak positive correlation with carbonates.

Weak correlation of elements $\mathrm{Co}, \mathrm{Cr}, \mathrm{Cu}, \mathrm{Ge}$, and As with quartz does not have geochemical justification.

Table 4. The correlation coefficient $(r)$ of the trace elements in mudstones with main minerals components

Tabela 4. Współczynnik korelacji (r) pierwiastków śladowych w mułowcach z głównymi składnikami mineralnymi

\begin{tabular}{|c|c|c|c|c|c|c|}
\hline & \multicolumn{6}{|c|}{ Mudstones } \\
\hline & 1 & 2 & 3 & 4 & 5 & 6 \\
\hline B & -0.27 & -0.1 & 0.06 & 0.31 & -0.48 & -0.67 \\
\hline $\mathrm{Ba}$ & -0.48 & 0.36 & 0.27 & 0.31 & -0.62 & -0.46 \\
\hline $\mathrm{Cd}$ & -0.41 & 0.68 & 0.69 & -0.04 & -0.19 & 0.53 \\
\hline Co & 0.45 & 0.18 & 0.12 & -0.26 & -0.33 & 0.71 \\
\hline $\mathrm{Cr}$ & 0.40 & -0.05 & -0.19 & -0.17 & -0.39 & -0.43 \\
\hline $\mathrm{Cu}$ & 0.49 & -0.34 & -0.18 & -0.18 & 0.02 & -0.02 \\
\hline $\mathrm{Ni}$ & 0.18 & 0.32 & 0.22 & -0.28 & -0.17 & 0.72 \\
\hline $\mathrm{Pb}$ & -0.29 & -0.03 & -0.09 & 0.48 & -0.69 & -0.14 \\
\hline $\mathrm{Zn}$ & -0.01 & 0.11 & 0.13 & -0.09 & -0.29 & 0.32 \\
\hline $\mathrm{Mn}$ & 0.27 & -0.39 & -0.49 & -0.01 & 0.43 & -0.76 \\
\hline $\mathrm{Ag}$ & -0.02 & 0.4 & 0.5 & -0.13 & -0.4 & -0.17 \\
\hline $\mathrm{Sr}$ & 0.19 & 0.06 & 0.34 & -0.2 & -0.07 & -0.14 \\
\hline $\mathrm{Ge}$ & 0.34 & -0.07 & 0.08 & -0.09 & -0.27 & -0.15 \\
\hline $\mathrm{Be}$ & 0.17 & 0.19 & 0.04 & -0.03 & -0.43 & -0.37 \\
\hline $\mathrm{Li}$ & -0.34 & -0.05 & -0.02 & 0.22 & -0.14 & 0.22 \\
\hline $\mathrm{V}$ & -0.03 & 0.44 & 0.57 & -0.11 & -0.37 & -0.70 \\
\hline As & 0.42 & -0.14 & 0.23 & -0.32 & -0.06 & -0.17 \\
\hline $\mathrm{Ga}$ & 0.17 & -0.4 & -0.1 & -0.03 & -0.08 & -0.26 \\
\hline
\end{tabular}

1 - quarz, 2 - muscovite/sericite, 3 - biotite/hydrobiotite/chlorite, 4 - clayey mass/clayem binder, 5 - siderite/siderite mass, 6 - organic matter 


\section{Conclusion}

Rocks from roofs, floors and bands in coal seams are represented mainly by: claystones and sandy claystones, less frequently sideritic claystones and mudstones, and locally fire clayey (tonstein), sideritic mudstones, clayey siderite and sandstones.

Distinguished types of rocks possess variable petrographic features, respective to the rock variety differentiated mineral composition. Their common characteristic property is the presence of significant admixtures of coal.

Chemical composition of rocks demonstrates their petrographic differentiation primarily by variable content of $\mathrm{SiO}_{2}$ and $\mathrm{Al}_{2} \mathrm{O}_{3}$, and in smaller scale also by variable content of the other chemical components.

Rocks, which coexist with coal seams, dependent on petrographic types, are characterised by differentiated concentration of trace elements. There also exist constant trends in trace elements content differentiation, regardless of the petrographic type of rocks. Since it has been found out that the dominant content exhibits Ba most frequently (above $100 \mathrm{ppm}$, up to $220 \mathrm{ppm}$ ) or more rarely $\mathrm{V}$ (often above $100 \mathrm{ppm}$, max. $274 \mathrm{ppm}$ ), by significant content (several dozen ppm) trace elements: $\mathrm{Zn}, \mathrm{Mn}, \mathrm{Pb}, \mathrm{Cu}, \mathrm{Cr}$, and $\mathrm{Ni}$.

The lowest content, variable from less than 1,0 ppm up to a few ppm, include elements $\mathrm{Cd}, \mathrm{Ag}$, and Sr.

The comparison of average contents of elements in different petrographic varieties of rocks led to a conclusion that numerous elements exhibit maximal average content $(\mathrm{V}, \mathrm{Ba}, \mathrm{Cd}, \mathrm{Cr}, \mathrm{Be})$ or close to maximal content ( $\mathrm{Mn}, \mathrm{Zn}, \mathrm{Cu}, \mathrm{As}, \mathrm{B}, \mathrm{Co}$, and $\mathrm{Li})$ in claystones.

There is also numerous groups of existing elements $(\mathrm{V}, \mathrm{Ba}, \mathrm{Sr}, \mathrm{Ag}, \mathrm{Ga}, \mathrm{As}, \mathrm{Cu}, \mathrm{Be}, \mathrm{B})$ which exhibited maximal or close to maximal average content in sandstones. High concentrations of trace elements in sandstones, which comprise aquifer horizons in Carboniferous rocks, increase their ability for infiltration by mineralised ground waters.

In the rest of analysed types of rock, i.e. sideritic claystones, mudstones, sideritic mudstones, as well as tonstein and clayey siderite, average contents of trace elements seldom reach maximal values.

Research on correlative relations between trace elements content and the presence of main mineral components of rock gave rather unexpected results since it has been found out that in the most frequently represented claystones and sideritic claystones predominant part of elements (B, Ni, Mn, $\mathrm{Cr}, \mathrm{Pb}, \mathrm{Ag}, \mathrm{Sr}, \mathrm{Be}, \mathrm{Li}, \mathrm{V}, \mathrm{As}$, and $\mathrm{Ge}$ ) exhibited correlation with the presence of organic matter (coal).

With the presence of organic matter, there exists a correlation with a significant group of trace elements in mudstones.

Expected correlation of clayey mineral content with a content of trace elements of dominant participation in claystones has been not confirmed. Only a few of these elements exhibited weak, or more frequently very weak, correlation with the content of clayey minerals. 
Relation between the content of trace elements and mineral composition of rocks is ambiguous, difficult to prove with adopted research methods and requires further investigation, i.e. with the use of microspectroscopy. Nevertheless, conducted research shows explicitly significant influence of the presence of organic matter in rocks on the content of trace elements. So far this influence was underestimated in analyses of differentiation of trace elements contents in rocks.

\section{Acknowledgements}

I would like to thank Professor B. Hanak, Silesian University of Technology, for their kind help and discussion.

The research was financed by the State Committee for Science Research of Poland (grant No. $5 T 12 B 022$ 23).

\section{REFERENCES}

Adamczyk, Z. 1994a. Obecność B, V, Ga, Zr, Ti, Mo, Cr w ilastych przerostach pokładów węgla warstw jaklowieckich i porębskich niecki jejkowickiej. XVII Sympozjum nt. Geologia formacji Węglonośnych Polski. PIG. Kraków. s. 9-12.

Adamczyk, Z. 1994b. Badania pierwiastków śladowych w przerostach ilastych pokładów węgla grupy warstw brzeżnych (namur A) w Rybnickim Okręgu Węglowym. Zeszyty Naukowe Politechniki Ślaskiej seria: Górnictwo nr 1234, Gliwice. s. 7-15.

Adamczyk, Z. 1997. The importance of tonstein from the Coal Seam 610 as the correlation horizon in the southwestern part of the Upper Silesian Coal Basin. Kwartalnik Geologiczny vol. 41, s. 309-314. PIG, Warszawa.

Adamczyk, Z. 1998. Studium petrograficzne wkładek płonnych z pokładów węgla górnych warstw brzeżnych niecki jejkowickiej. Prace Geologiczne 144, PAN. Wyd. IGSMiE PAN, Kraków.

Admakin, L.A. 1995. Classification and Nomenclature of Tonsteins. Litol. Polezn. Iskop. no. 6.

Admakin, L.A. 2001. Lithogenetic Indicators of Tonsteins. Lithology and Mineral Resouces vol. 36, no. 1.

Bohor, B.F. and Triplehorn, D.M. 1993. Tonsteins: altered volcanic-ash layers in coal-bearing sequences. Geological Society of America, Special Paper 285.

Dai et al. 2011 - Dai, S., Wang, X., Zhou, Y., Hower, J.C., Li, D. and Chen, W. 2011. Chemical and mineralogical composition of silicic, mafic and alkali tonstein in the late Permian coals from the Songzao Coalfield, Chongqing, southwest China. Chemical Geology 282, 29-44.

Dill et al. 1991 - Dill, H., Teschner, M. and Wehner, H. 1991. Geochemistry and lithofacies of Permo-Carboniferous carbonaceous rocks from the southwestern edge of the Bohemian Massif (Germany). A contribution to facies analysis of continental anoxic enwironments. International Journal of Coal Geology 18, s. 251-291.

Dopita, M. and Kralik, J. 1977. Uhelne tonsteiny ostravsko-karvinskeho reviru. Ostrawa.

Chodyniecka, L. 1973. Karbońskie sferosyderyty ilaste z Górnośląskiego Zagłębia Węglowego (Studium mineralogiczno-chemiczne). Zeszyty Naukowe Politechniki Ślqskiej, seria Górnictwo nr 369.

Chodyniecka, L. and Wilk, A. 1979. Przyczynek do poznania skał ilastych z kopalni „Murcki”. Zeszyty Naukowe Politechniki Ślaskiej, seria Górnictwo nr 102, s.79-85. Gliwice.

Chodyniecka et al. - Chodyniecka, L., Biss, D. and Mikołajczyk, P. 1994. Charakterystyka mineralogiczno-petrograficzna i możliwości wykorzystania przerostów występujących w niektórych pokładach węgla w KWK „Sośnica” (GZW). Zeszyty Naukowe Politechniki Ślaskiej, seria: Górnictwo nr 1234, Gliwice. s. $16-30$. 
Ferm et al. - Ferm, J.C., Weisenfluh, G.A. and Smith, G.C. 2002. A method for development of a system of identification for Appalachian coal-bearing rocks. International Journal of Coal Geology vol. 49, issues 2-3, p. 93-104.

Gabzdyl, W. 1969. Charakterystyka petrograficzno-facjalna pokładów węgla i skał towarzyszących w kopalni „Jastrzębie” (Rybnicki Okręg Węglowy). Prace Geologiczne 55 - PAN. Wyd. Geol., Warszawa.

Gabzdyl, W. 1984. Dalsze stwierdzenia tonsztajnu w pokładzie 610 GZW. Przegląd Geologiczny nr 1. Wyd. Geol. Warszawa.

Gabzdyl, W. 1990. Charakterystyka petrograficzna tonsteinów GZW. Zeszyty Naukowe Politechniki Ślaskiej, seria Górnictwo nr 187, s. 7-24.

Gabzdyl, W. and Ryszka, J. 1995. Phosphorus - rich Coaly Tonsteins and Coal Seams in Silesian. XIII International Congress on Carboniferous - Permian. Kraków. p. 40-41.

Gorol, M. 1996. Charakterystyka petrograficzno-facjalna pokładu węgla 349 z kopalni „Chwałowice”. Zeszyty Naukowe Politechniki Śląkiej, seria Górnictwo nr 230, s. 75-107.

Hanak, B. and Kokowska, M. 2002. Próba określenia zależności pomiędzy składem chemicznym i wybranymi wskaźnikami geochemicznymi w skałach stropowych jako potencjalnych odpadach pogórniczych z niektórych pokładów warstw porębskich Górnośląskiego Zagłębia Węglowego. Gospodarka Surowcami Mineralnymi-Mineral Resources Management t. 18, z. 3, Kraków, s. 77-93.

Hanak, B. and Kokowska-Pawłowska, M. 2003. Charakterystyka zmienności udziału wybranych pierwiastków śladowych w skałach towarzyszących pokładom węgla 610 i 620. Zeszyty Naukowe Politechniki Ślqskiej, seria Górnictwo nr 256, Gliwice, s. 95-101.

Hanak, B. and Kokowska-Pawłowska, M. 2004. Zróżnicowanie zawartości pierwiastków śladowych i podrzędnych w skałach płonnych i popiołach węgla z pokład 620. Zeszyty Naukowe Politechniki Ślaskiej, seria Górnictwo nr 260, s. 155-165.

Hanak, B. and Kokowska-Pawłowska, M. 2006. Charakterystyka koncentracji pierwiastków śladowych w skałach towarzyszących z pokładu 630. Zeszyty Naukowe Politechniki Śląskiej, seria Górnictwo nr 273, s. $28-37$.

Hawa Bibi et al. 2008 - Hawa Bibi, M., Farque, A., Hirokai, I. 2008. Mobility of arsenic and trace element inventories in sediment cores from Masuda City, southwestern Japan. Environmental Geology 54, 791-803.

Kabata-Pendias, A. and Pendias, H. 1999. Biogeochemia pierwiastków śladowych. PWN, Warszawa.

Krawczyk, A. and Słomka, T. 1986. Podstawowe metody matematyczne w geologii. Skrypty Uczelniane 1026. AGH. Kraków.

Kuhl, J. 1955. Petrograficzna klasyfikacja skał towarzyszących pokładom węgla w Zagłębiu Górnego Śląska. Prace $G I G$, kom. nr 171. Katowice.

Łapot, W. 1992. Zróżnicowanie petrograficzne tonsteinów Górnośląskiego Zagłębia Węglowego. Prace Naukowe Uniw. Śl., nr 1326. Katowice.

Migaszewski, Z.M. and Gałuszka, A. 2003. Zarys geochemii środowiska. Wyd. Akad. Świetokrzyskiej. Kielce.

Parzentny, H. 1992. Częstość występowania ołowiu w węglach i łupkach węglowych z Górnośląskiego Zagłębia Węglowego. Przegląd Górniczy nr 2, s. 25-29.

Parzentny, H. 1999. Petrograficzna i geofizyczna charakterystyka skupień nieorganicznej substancji mineralnej w pokładzie węgla 504 w rejonie Czeladzi. Przegląd Górniczy nr 10, s. 32-40.

Polański, A. 1988. Podstawy Geochemii. Wyd. Geol. Warszawa.

Ryka, W. and Maliszewska, A. 1991. Stownik petrograficzny. Wyd. Geol., Warszawa.

Ryszka, J. and Gabzdyl, W. 1986. Tonsztajny i inne skały tufogeniczne jako wskaźnik czasu, ich znaczenie dla rozpoznawania i eksploatacji pokładów węgla w GZW. Zeszyty Naukowe Politechniki Ślaskiej, seria Górnictwo nr 149.

Shepard, S.P. 1973. Submarine Geology. Harper and Bross. New York [W:] Łydka K., 1975. Petrologia skat osadowych. Wyd. Geol.

Trela, Z. and Tabor, A. 1984. Prognozowanie jakości odpadów powęglowych na tle badań geologicznych i dokumentowania złóż węgla. Mat. Ogólnokrajowej Konferencji na temat: Problemy badań węgla w pracach geologiczno-złożowych $w$ aspekcie nowych technologii jego utylizacji. Jaworze. 
Ward et al. 2005 - Ward, C.R., Nunt-Jaruwong, S., Swanson, J. 2005. Use of mineralogical analysis in geotechnical assessment of rock strata for coal mining. International Journal of Coal Geology vol. 64, issue 1-2, p. $156-171$

Yarali et al. 2008 - Yarali, O., Yasar, E., Bacak, G. and Ranjith, P.G. 2008. A study of rock abrasivity and tool wear in Coal Measures Rocks. International Journal of Coal Geology vol. 74, issue 1, p. 53-66.

Zhou et al. 2000 - Zhou, Y., Bohor, B.F. and Ren, Y. 2000. Trace element geochemistry of altered volcanic ash layers (tonsteins) in Late Permian coal-bearing formations of eastern Yunnan and western Guizhou Province, China. International Journal of Coal Geology 44.

\title{
ZRÓŻNICOWANIE PETROGRAFICZNO-MINERALOGICZNE SKAL WSPÓŁWYSTĘPUJACYCH Z WYBRANYMI POKLADAMI WĘGLA Z WARSTW PORĘBSKICH I JEGO WPLYW NA ZAWARTOŚĆ PIERWIASTKÓW ŚLADOWYCH
}

\author{
Słowa kluczowe \\ skały współwystępujące, skały stropowe, skały spagowe, przerosty, \\ pierwiastki śladowe, warstwy porębskie, pokłady węgla 610, 620 i 630

\section{Streszczenie}

Skały współwystępujące z węglem w wybranych pokładach warstw porębskich $(610,620,630)$ reprezentowane są najczęściej przez iłowce oraz iłowce syderytyczne, a rzadziej przez mułowce i mułowce syderytyczmne. Sporadycznie występują piaskowce. Stwierdzono także występowanie przerostu $\mathrm{z}$ tonsteinem. Zależnie od odmiany petrograficznej skał stwierdzono w nich zróżnicowanie zawartości pierwiastków śladowych (Ba, $\mathrm{Zn}, \mathrm{Mn}, \mathrm{V}, \mathrm{Cr}, \mathrm{Cu}, \mathrm{Ni}, \mathrm{Pb}, \mathrm{As}, \mathrm{Ga}, \mathrm{B}, \mathrm{Co}, \mathrm{Ge}, \mathrm{Be}, \mathrm{Li}, \mathrm{Cd}$, $\mathrm{Ag}, \mathrm{Sr}-\mathrm{w}$ kolejności malejącego udziału). Znaczna część pierwiastków wykazała wysoki i często dominujący udział w iłowcach. Stwierdzono także regionalne zróżnicowanie zawartości pierwiastków śladowych w skałach.

Badania korelacji pomiędzy zawartością pierwiastków śladowych a zawartością głównych minerałów w skałach potwierdziły powinowactwo wielu pierwiastków śladowych z substancją organiczną, minerałami ilastymi i węglanami. Zwraca uwagę występowanie korelacji licznych pierwiastków śladowych z substancją organiczną (węglem) przy stosunkowo niewielkiej liczbie pierwiastków korelujących z minerałami ilastymi. 


\title{
PETROGRAPHIC AND MINERAL VARIABILITY OF THE ROCKS ACCOMPANYING SELECTED COAL SEAMS OF THE PORUBA BEDS AND THEIR INFLUENCE OF THE TRACE ELEMENTS CONTENT
}

\author{
Keywords \\ rocks accompanying, roof rocks, floor rocks, band rocks, trace elements, \\ Poruba beds, 610, 620, 630 coal seam
}

\begin{abstract}
The rocks accomanying with coal in selected Poruba beds $(610,620,630$ coal seams) showed the diversification of mineralogical and petrographic composition. Most often there are claystones (including syderitic claystones), rarely mudstones (including syderitic mudstones) and sporadically sandstones. The presence of tonstein was also found. In the rocks was found variability of trace elements content (Ba, Zn, Mn, V, Cr, Cu, Ni, Pb, As, Ga, B, Co, Ge, Be, Li, Cd, Ag, Sr - in order of decreasing participation) dependent on rocks petrographic variety. Large part of elements showed high and often dominant participation in claystones.

Correlation analysis between trace elements concentration and main minerals content confirmed the affinity of many trace elements with clay minerals, carbonates and organic substance. Noteworthy, the correlation of many elements with mica in syderitic claystones.
\end{abstract}

